\title{
Chemistry and Evolution of Desert Ephemeral Stream Runoff
}

\section{Omar M. Al-Qudah ${ }^{1,2 *}$, John C. Walton ${ }^{1}$, and Arturo Woocay ${ }^{1,3}$}

${ }^{1}$ Civil Engineering Department, The University of Texas at El Paso, $500 \mathrm{~W}$ University Ave, El-Paso, TX 79968, USA.

${ }^{2}$ Department of Agriculture and Environmental Science and Cooperative Research Program, Lincoln University, Jefferson City, MO 65101.

${ }^{3}$ División de Estudios de Posgrado e Investigación, Instituto Tecnológico de Ciudad Juárez, Ave. Tecnológico 1340, Ciudad Juárez, CHIH 32500, México.

* Corresponding author:

Omar M. Al-Qudah, Ph.D.

2512 Southridge Dr. Apt\#A

Jefferson City, MO 65109

(972) 801-8539

omal@miners.utep.edu

al-qudaho@lincolnu.edu

alqudah.omar75@hotmail.com 


\begin{abstract}
The study investigates how water chemistry evolves as ephemeral stream runoff is formed through the interaction of sediments and precipitation in the Amargosa Desert region and by analogy other desert regions. In this study, thirty lysimeters were installed in the major arroyos in the Amargosa Desert to capture runoff water. The sampling process included sediment, precipitation, and runoff water chemistry. Innovative and low cost methods were used to measure the chemical composition of the resulting runoff and examined some of the important processes affecting the runoff chemistry. Results of the analytical and statistical analyses indicate that runoff salinity is low as a result of net salt accumulation in sediments. Chemical behavior between precipitation and runoff is classified as leached (TDS, alkalinity, $\mathrm{Ca}, \mathrm{Mg}, \mathrm{K}, \mathrm{Na}, \mathrm{Ba}, \mathrm{Cs}$, $\mathrm{Li}, \mathrm{Sr}, \mathrm{Fe}, \mathrm{Ni}$ ), nutrient (Br, As, $\left.\mathrm{SO}_{4}{ }^{2-}, \mathrm{PO}_{4}{ }^{3-}, \mathrm{NO}_{3}{ }^{-}, \mathrm{Rb}, \mathrm{B}, \mathrm{Cu}, \mathrm{Zn}, \mathrm{V}\right)$, scavenged (U, F), and conservative (Al, Mo, Mn). Bromide behaves as a nutrient meaning the chloride/bromide ratio, a common tracer of groundwater sources, is not conservative. Runoff chloride, sulfate, and sodium are predominantly associated with concentrations of the same ions in sediment. Trace elements are more closely associated with precipitation chemistry.
\end{abstract}

Keywords: Amargosa Desert; Ephemeral Arroyos; Solute Transport; Lysimeter; Redundancy Analysis

\title{
1. Introduction
}

Climate change models predict that future precipitation will be more episodic, leading potentially to larger geographic areas being dominated by ephemeral streams. Surface runoff from ephemeral streams in desert regions could be an important water resource if increasingly captured for beneficial use by dams and engineered recharge facilities with rising future water 
demand. Relatively little information is available about the chemistry of ephemeral streams runoff in desert regions and how it relates to precipitation and sediment chemistry.

Many models have been developed to study the transport of chemical constituents from soil into runoff, and the most used approaches were: the lumped, mixing layer approach and the diffusion approach. The mixing layer approach suggests that rainfall, soil water, and runoff water mix instantaneously and produce a thin mixing film just below the soil surface, and that there is no transport toward this layer from deeper soil (Ahuja, 1990; Steenhuis et al., 1994; Zhang et al., 1999). The diffusion approach assumes that chemical constituents are transferred from soil into runoff in a diffusion mechanism, and ignoring the effect of rainfall (Wallach and van Genuchten, 1990; Wallach, 1991). In general, these approaches can be fitted to experimental data by calibrating one or more unknown parameters so it remains unclear how multiple processes interact to facilitate chemical transport between soil and runoff (Barry et al, 2013). A recently developed approach (Gao et al., 2004, 2005; Walter et al., 2007) produced from merging the two previous approaches as the rainfall-driven transport of chemical constituents from the mixing layer into runoff, and the diffusion-driven transport from deeper soil layers into the mixing layer and infiltration. However, these models present theoretical approaches based upon laboratory experiments without supporting field data.

The scarcity of data and the lack of high quality observations as well as the potentially discontinuous occurrence of flow in both space and time are the major characteristics of the ephemeral streams in arid regions (Al-Qudah et al., 2014; 2010). Some authors (e.g., Fisher and Minckley, 1978; and Native et al., 1997) have studied desert flash floods (runoff) as a dilution phenomenon in terms of dissolved substances, in which low conductivity rainwater dilutes salts accumulated by evaporative concentration of precipitation. Fisher and Minckley (1978) 
described the changes in selected chemical parameters during a single flash flooding event on Sycamore Creek, Arizona, an intermittent stream. Their results showed that the major anion, bicarbonate, and conductivity followed a dilution pattern; whereas nitrate, phosphate and iron varied widely through the cycle. Native et al (1997) used major ion chemistry and water stable isotopes to evaluate the processes affecting salinization of precipitation and runoff in the Negev Desert, Israel, and their results showed that, a) calcium and bicarbonate are the dominant ions in both precipitation and runoff water; b) runoff salinity (expressed as total dissolved solids) is higher than that of the precipitation by almost one order of magnitude; c) variability in the relative salt enrichment by a factor of three to five in the runoff with respect to precipitation; and, d) the ranges and mean values of the isotopic composition of runoff water are light with respect to those observed in precipitation. Their results indicate that the dilution phenomena of floods are partially offset by runoff and increased leaching from the ephemeral stream beds and surrounding lands and dissolution of solutes from newly exposed rock and soil minerals as well as from suspended particles.

In the Amargosa Desert, runoff occurs only as a transient response to precipitation events, which can be sudden and intense. The Great Basin desert is known for flash floods that start and end abruptly, carrying objects as large as boulders and cars when they do strike (Beck and Glancy, 1995). Run-on occurs when water from higher areas accumulates in lower areas, which creates the potential for localized increases in infiltration (DOE-OCRWM, 2006). Waterchemicals transportation along the vadose zone has been intensively studied in the vicinity of the Amargosa Desert (Montazer and Wilson, 1984; Classsen et al, 1985 Savard, 1998; Dettinger, 1989; Fabryka-Martin et al., 1998; Flint et al., 2002, 2001a, b; Hevesi et al., 2003, 2002; Russell et al, 2007; Al-Qudah et al., 2011). However, the chemical evolution of surface runoff in the 
Amargosa Desert region received little attention. The purpose of this study was to provide insight into chemical transformations (chemical losses and gains) in the precipitation/sediment interaction that creates runoff chemistry in an arid region. A plausible hypothesis was that stormwater from small storms would dissolve and transport the soluble salts that accumulate in the shallow sediments leading to ephemeral water with high total dissolved solids (TDS) and chloride.

\section{Description of the Study Area}

The Amargosa Desert lays in southern Nevada, USA north east of Death Valley, between the Mojave Desert and the southern boundary of the Great Basin, and is presented in Figure 1. The area is drained by the ephemeral Amargosa River drainage basin which is the major stream channel drainage area to Death Valley. Fortymile Wash, an ephemeral stream that originates in the uplands north of Yucca Mountain between Timber Mountain and Shoshone Mountain, flows southward along the east of Yucca Mountain and fans out in the northern part of the Amargosa Desert just north of Highway 95. Near U.S. Highway 95, the Fortymile Wash channel changes from being moderately confined to several distributary channels that are poorly confined. This poorly-defined, distributary pattern persists downstream to its confluence with the Amargosa River. A deep carbonate aquifer, locally up to 4,600 meter (m) thick (Stetzenbach et al., 2001) and composed mainly of Paleozoic limestones and dolomites (Flint et al., 2001b), underlies most of the tuff volcanic rocks and the desert valley sandy soil alluvial fill (Kwicklis et al., 2003).

The present climate in the Amargosa Desert region is considered arid to semiarid. The distribution of precipitation is related to the altitude and latitude of the land surface; the higher mountains in the northern part of the Amargosa Desert receive the largest amounts of 
precipitation and the valley the least. The majority of the precipitation falls in the winter, while most of the remaining precipitation occurs in the summer as thunderstorms. The average annual precipitation ranges from less than 130 millimeters $(\mathrm{mm})$ at lower elevations $(\leq 600 \mathrm{~m}$ above mean sea level [amsl]) to more than $280 \mathrm{~mm}$ at higher elevations ( $\geq 1200 \mathrm{~m}$-amsl), and the annual average precipitation is considered as 170 millimeter per year (mm/yr) (SNL, 2008; Stetzenbach et al., 2007; Flint et al., 2002). Between 2001 and 2005, the annual average evapotranspiration rate, air temperature, soil temperature, and relative humidity were, respectively, $147.7-232.6 \mathrm{~mm} / \mathrm{yr}, 18.0$ - 18.4 degrees Celsius $\left({ }^{\circ} \mathrm{C}\right), 21.1-21.9{ }^{\circ} \mathrm{C}$, and 21.7 33.3 percent (\%) (Johnson et al., 2007). Recharge in the region is generally considered sparse and derived from precipitation infiltrating at high elevations (> $1200 \mathrm{~m}$-amsl) and ephemeral streams runoff at low elevations (<1200 m-amsl) (Harrill, 1976; Dettinger, 1989; Flint et al., 2001a,b; Russell and Minor, 2002), and most conceptual models have estimated net infiltration to be $<3 \%$ of the precipitation with the most prevalent assuming less than $1 \mathrm{~mm} / \mathrm{yr}$ (Flint et al., 2001a,b).

In the vicinity of the Amargosa Desert, Beck and Glancy (1995) have documented the flow in the Fortymile Wash and Amargosa River during some flash flood events occurring between 1983 and 1995. This documentation confirms that Fortymile Wash and the Amargosa River have the potential, in the present climatic regime, to transport dissolved and particulate materials beyond the confines of the Nevada nuclear test site (NTS) and Yucca Mountain areas during moderate and severe streamflow.

\section{Methods}

\subsection{Runoff, Precipitation, and Sediment Sampling}


Figure 2 portrays the sequence of the lysimeter and sediment methods described here. A simple lysimeter (Figures 2a and 2b) was designed to collect runoff that has contacted and leached some of the top sandy soil in order to measure its chemical characteristics and better understand its chemical evolution as the water moved from precipitation to runoff in the Amargosa Desert's ephemeral streams. The lysimeters were placed - in pre-selected arroyos in the Amargosa Desert region (Al-Qudah et al., 2010) - at locations where water is likely to pool and where sufficient depth of sediment facilitates digging a hole for emplacement (Figures $2 \mathrm{c}$, 2d). To the extent possible, lysimeters were placed in low gradient (depositional) portions of the arroyo to minimize washing out during storms (Figure 2e). The top of the lysimeter was 25-50 mm below the undisturbed surface of the arroyo, and this gap was covered with washed silica sand (Figures $2 \mathrm{c}$ and $2 \mathrm{~d}$ ). At each location, a T-post (fence post) was installed to identify the site and serve as the mount for a rain gauge. The T-post was pounded on a flank of the wash to prevent it from being washed away during storm events (Figure 2f). In total, thirty lysimeters filled with washed silica sand (Figure 2b) were installed between January and September 2009 at thirty different locations in the vicinity of the Amargosa Desert with an elevation-range between 600 and 1300 m-amsl as shown in Figure 1.

Three storm events occurred during the study period, in February, 2009; January, 2010; and December, 2010, with total depth/precipitation rates of, respectively, $(23.9 ; 4.1),(39.9 ; 3.8)$, and $(47.8 ; 3.3)(\mathrm{mm} / \mathrm{event}$; mm/hour) (CEMP, 2013). The storm events were local, with runoff only occurring in stretches of the channels rather than being continuous from distant highlands. However, the storm events were enough to produce runoff and lysimeter infiltration in the washes (Figures 2f, $2 \mathrm{~g}$ and $2 \mathrm{~h}$ ). 
Samples collected from each site location included runoff (lysimeter water), precipitation, and sediment. Runoff and precipitation samples were collected, preserved, and shipped based on the Standards Methods for the Examination of Water and Wastewater (SMEWW) (Clescerl et al., 2000). Subsequent to arrival at each location (shortly within a week after each storm occurred): (1) rain gauge readings were recorded before pouring their water in a high density polyethylene (HDPE) bottle; (2) a peristaltic pump was attached to the lysimeter, and the first 25 milliliter (ml) of sample was purged; (3) after purging was completed, infiltrating water samples were collected in different bottle types consistent with the required chemical constituents (Figure $2 \mathrm{i})$; (4) prior to collecting samples requiring filtering from each sampling location, a clean piece of silicone tubing was installed on the peristaltic pump along with a new large-capacity $(0.45$ micrometer) filter on the discharge end of the tubing; (5) after sampling was completed, the remaining water (if any) from the lysimeter was purged to provide space for collection during the next runoff event; and (6) alkalinity, $\mathrm{pH}$, and $\mathrm{EC}$ for precipitation and runoff samples were measured at each site after sampling completed (Figure 2j).

The sediment samples in this study represent a leaching of the shallow sediment in the stream bottom, which is one type of sediment that runoff water will interact with before infiltrating. Sediment samples (Figure 2k) were collected from each site at the time of lysimeter installations, and shortly after each of the storm events (i.e., sediments were sampled pre and post-storms). Sediment samples were collected, preserved, and shipped based on the American Society for Testing and Materials (ASTM) standards (D4700-91-06; D4220-95-07). The collected sediment samples were divided into two subsamples to measure its physical and chemical properties. The first group of the sediment samples was extracted in the lab according to ASTM (D4542-07), by mixing $2 \mathrm{~kg}$ of sediment with 3.76 liter of distilled water, letting the 
mixture settle overnight and then separating the leachate (Figure 21). The ions leached from sediments represent the soluble species from the accumulation of atmospheric dryfall/dust, evaporite films from non-runoff generating precipitation events, and biological input (e.g., feces, urine). The second group of the sediment samples was analyzed at the Nye County nuclear waste repository project office laboratory (NWRPO) based on ASTM standards (D422-63-07; D85406; D1140-06; D2216-05) for the following physical properties: gravimetric water contents, hygroscopic water content, bulk density, solid density, porosity, particle size distribution, uniformity coefficient, and the soil textural term.

Runoff (lysimeter water), precipitation, and sediment water (sediment extract) samples were analyzed based on SMEWW standards (Clescerl et al., 2000) for the major anions and cations $\left(\mathrm{Cl}^{-}, \mathrm{HCO}_{3}^{-}, \mathrm{SO}_{4}{ }^{2-}, \mathrm{Ca}^{2+}, \mathrm{Mg}^{2+}, \mathrm{K}^{+}\right.$, and $\left.\mathrm{Na}^{+}\right)$, some other ions $\left(\mathrm{Br}^{-}, \mathrm{F}^{-}, \mathrm{NO}_{3}{ }^{-}, \mathrm{PO}_{4}{ }^{3-}, \mathrm{Li}^{+}\right)$, and trace elements (Ba, Cs, $\mathrm{Sr}, \mathrm{Fe}, \mathrm{Ni}, \mathrm{Rb}, \mathrm{Zn}, \mathrm{As}, \mathrm{B}, \mathrm{Cu}, \mathrm{V}, \mathrm{U}, \mathrm{Al}, \mathrm{Mo}$, and $\mathrm{Mn}$ ) using inductively coupled plasma mass spectrometry (ICP-MS) and ion-exchange chromatography (IEC) machines, whereas water stable isotopes, oxygen-18 $\left({ }^{18} \mathrm{O}\right)$ and deuterium $\left({ }^{2} \mathrm{H}\right)$, were determined in commercial laboratories.

\section{Results and Discussion}

\subsection{Analytical Results Summary}

In total, 167 runoff (lysimeter water) samples were collected after the three main storms that occurred during the study period. Sample volumes ranged between 80 and 3,000 $\mathrm{ml}$, with a mean of 1,360 ml. After the January, 2010 storm event, 45 precipitation samples were collected from the installed rain gauges; rainfall amounts ranged between 25 and $75 \mathrm{~mm}$, with a mean of $43 \mathrm{~mm}$. In total, 182 sediment samples were collected from all site locations before and after the storm events between January, 2009 and December, 2010. The sediment physical properties 
found in this study were: (1) porosity ranged between 0.44 and 0.55 with a mean value of 0.47 , (2) solid density ranged between 2.50 and $2.65 \mathrm{~g} / \mathrm{ml}$ with a mean value of $2.58 \mathrm{~g} / \mathrm{ml}$, (3) most of the sediment is sand (62\%), followed by gravel (27\%), silt (9\%), and clay (2\%); sandy soil presents the main textural class for twenty-six site locations, silty-sand (loamy sand) at three sites, and clay-silt (silt loam) at one site. In the Amargosa Desert the thickness of the sediment layer over bedrock ranges from $<20 \mathrm{~cm}$ at high elevation to $>20 \mathrm{~m}$ at low elevation (Johnson et al., 2007; Guerta et al., 1987).

The basic statistics of the mean chemical analysis (raw values before normalization) of collected runoff (lysimeter water), precipitation, and sediment extract (sediment water) samples before and after storm events are summarized in Table 1, and their ion ratios are shown in Table 2. The individual ion concentrations in sediment water are arbitrary in the sense that they depend upon the volume of water added per $\mathrm{kg}$ of sample during leaching (1.88 liter $/ \mathrm{kg}$ ). Comparison of concentrations of sediment concentrations pre and post storm events indicates that most ions are depleted during the storm events. Going from precipitation to runoff most analytes increase in concentration, the exceptions being (Table 1) nitrate, bromide, arsenic, and cesium.

The ratios in Table 2 reveal trends and allow comparison of sediment with other concentrations. The ratio of sodium to chloride begins at near the seawater level in precipitation then increases as precipitation interacts with sediment to form runoff. The net loss of sodium from sediments is also visible in the pre and post storm sediment ratios. The mean concentrations of $\mathrm{Cl}^{-}$and $\mathrm{Br}^{-}$in precipitation were 2.7 and $0.4 \mathrm{ppm}$, respectively, compared to the global mean precipitation meteoric values of (3.74 and $0.0132 \mathrm{ppm}$ ) (Neal et al., 2007); $\mathrm{Cl}^{-} / \mathrm{Br}^{-}$equivalent ratio ranged between 5.5 and 17 with a mean value of 11.2, and all the precipitation samples fall below the value of global meteoric precipitation ratio (110 to 340 ; mean $=220$ ) (Davis et al., 
1998, 2004; Fabryka-Martin et al., 1997, 1998). The chloride to bromide ratio increases noticeably in runoff, beyond either precipitation or sediment levels. This is indicative of selective uptake, presumably biological, which decreases the importance of bromide as an environmental tracer as previously concluded, e.g., Davis et al (2004) and Bowman and Rice (1985).

\subsection{Evaporation Corrected Evolution of Individual Constituents}

Comparison of individual analyte behavior between sample types required normalization. Normalization serves several functions: (a) the sediment sample concentrations are related to the volume of leaching water added and must be normalized in order to compare with other samples; and (b) chemical evolution needs to be separated from degree of evaporation. The logarithmicion ratios diagram, presented in Figure 3, provides insight into chemical evolution by examining median concentrations normalized by sample chloride concentration relative to precipitation (considering chloride as a conservative ion). Changes in an ion relative to chloride indicate a source or sink for that ion after controlling for evaporative concentration or dilution.

Processes affecting the concentration of chemical constituents (normalized values) in the water samples are shown in Figure 3 as four general behaviors in terms of how they behave within the domain of runoff generation, (a) leached behavior occurs when the ion or element appears to be leached from the sediment by the precipitation and runoff-water. Chemical constituents accumulated in the sediment water (pre-storm samples) are larger than that in the precipitation, whereas the concentrations in runoff are in between (i.e., sediment water> runoff > precipitation). Example, magnesium and sodium presented leached behavior indicating that surficial sediments are a net source for these elements; (b) nutrient behavior is when microbial or plant preferential (relative to chloride) uptake appears to occur. In this pattern the chemical constituent concentrations in the runoff samples are lower than that in pre-storm sediment water 
and precipitation samples (i.e., precipitation \& sediment water> runoff). Example, bromide, arsenic, sulfate, and total- $\mathrm{N}$ follow nutrient behavior; (c) scavenged pattern is when the chemical constituents accumulated in the precipitation have greater concentrations than that in runoff and pre-storm sediment water (i.e., precipitation> runoff> sediment water); suggesting that the element is scavenged from the precipitation water as it contacts sediment (i.e., accumulating in the sediments), as shown in uranium and fluoride trends. Both nutrient and scavenged behaviors exhibit net loss of analytes between precipitation and runoff. The labels are descriptive and the distinction between nutrient and scavenged is not definitive; (d) conservative behavior is when precipitation $\approx$ runoff and is taken as the default behavior whenever none of the other behaviors are statistically significant. This behavior can be caused by different processes (e.g., slow kinetics) that cause runoff concentrations to be approximately equal to precipitation; aluminum, manganese, and molybdenum present conservative behavior. All categorizations listed in Figure 3, with the exception of conservative (the default classification), are statistically significant by ANOVA at $\mathrm{p}<0.05$.

\subsection{Equilibrium Controls (PHREEQC)}

The computer program PHREEQC is capable of describing a variety of geochemical processes in aqueous-systems (Parkhurst and Appelo, 1999). PHREEQC was used to calculate the thermodynamic equilibrium saturation indices (SI) for mineral species, based on anion and cation mean concentrations of sediment water and runoff as shown in Table 3. The saturation index (SI) is defined as the logarithm of the ratio of the ion activity product (IAP) of the component ions of the solid in solution to the solubility product $(\mathrm{K})$ for the solid $[\mathrm{SI}=\log \mathrm{IAP} / \mathrm{K}]$.

PHREEQC simulations indicate that the precipitation samples were under saturated with all minerals considered. Simulations of sediment waters were performed assuming all the leach 
water was evaporated down to measured in situ moisture content prior to calculating the saturation indices. Saturation indices obtained for pre-storm sediment show supersaturation with respect to calcium and magnesium carbonates (calcite and dolomite), chlorite, hydroxyapatite, rhodochrosite, and talc; near saturation with respect calcium clays and illite; and all other minerals tested are under saturated. In the case of post-storm sediment water, all considered minerals in Table 3 show lower saturation than that in pre-storm event. In this context the supersaturated minerals were likely dissolved by the leach water, mimicking the process that would occur when streambed sediments interact with runoff water.

Simulations indicate that $\mathrm{Ca}, \mathrm{Ca}-\mathrm{Mg}$, and $\mathrm{Mg}$ carbonates (calcite and dolomite), as well as, anorthite, rhodochrosite, and willemiteare are in near saturation in runoff water. Secondary clay minerals as indicated by Ca-montmorillonite, illite, chlorite, hydroxyaptite, $K$-feldspar, and talc are supersaturated. Alkalinity can come from the dissolution of carbonates and/or weathering of silicate minerals as shown in Equations 1 and 2 (White, 1979; Hem, 1992).

$$
\begin{array}{cc}
\mathrm{MCO}_{3} \rightarrow \mathrm{M}^{2+}+\mathrm{CO}_{3}{ }^{2-} & \mathrm{Eq.1} \\
\left.(\text { Silicaterock })\left(\mathrm{M}^{+}\right)+\mathrm{H}_{2} \mathrm{CO}_{3}\right) \rightarrow(\text { Silicaterock })\left(\mathrm{H}^{+}\right)+\mathrm{M}^{+}+\mathrm{HCO}_{3}{ }^{-} & \text {Eq.2 }
\end{array}
$$

The near equilibrium of runoff with $\mathrm{Ca}-\mathrm{Mg}$ carbonates suggests rapid reversible dissolution of these minerals from the sediment giving higher $\mathrm{Ca}, \mathrm{Mg}$ and alkalinity in runoff relative to precipitation. Under saturation with silicate minerals such as albite, and $K$-feldspar is consistent with irreversible silicate weathering leading to increases of $\mathrm{Na}, \mathrm{K}$, and alkalinity (mainly non-carbonated alkalinity as indicated by its ratios in Table 2). Secondary mineral formation suggested by supersaturation with $\mathrm{Ca} / \mathrm{Mg}$-clays appears to be occurring more slowly, allowing the sediments to be net sources of most cations (e.g., $\mathrm{Na}$ and $\mathrm{Mg}$ ).

\subsection{Piper Plot}


Figure 4 presents a Piper diagram for the precipitation, runoff, and sediment water samples. The Piper diagram, where the diamond shape in the middle reflects the hydrochemical facies presented by the lower triangles, allows comparison of a large number of samples on the same figure, shows clustering of samples and water type, used to classify water as hydrochemical facies, and controls for evaporative concentration by examining equivalent ratios for precipitation, sediment water, and runoff, but only examines major ions. The idea of hydrogeochemical facies is the classification of waters according to the relative proportions of major ions (Drever, 1997). Water plotting in the upper half of both the cation and anion triangles would be referred to as magnesium sulfate-type water (Drever, 1997). Water plotting in the lower left hand side of the cation triangle and the lower right hand side of the anion triangle would be calcium chloride-type water (Drever, 1997). If both cation and anion compositions plot in the middle of the two triangles, then the waters would be referred to as mixed cation-mixed anion-types (Drever, 1997). If a water plots near the middle of one of the edges of the triangles, then one might refer to, e.g., magnesium-calcium sulfate water (Drever, 1997).

Precipitation data plot in zones 5, 7, and 8 on the Piper diagram, indicating (Ca-Na-Cl$\left.\mathrm{HCO}_{3}\right)$ water-type. The pre-storm sediment water was dominated by $\left(\mathrm{CO}_{3} / \mathrm{HCO}_{3}-\mathrm{Na}\right)$ water facies and shifts in the $\mathrm{Ca}$ direction post storm indicating preferential leaching of the more soluble $\mathrm{Na}$ and $\mathrm{K}$. In all sediment water samples, carbonate and bicarbonate dominate chloride and sulfate, and there is a range of cation distributions with most samples dominated by calcium and magnesium but a tail of samples ranging into sodium and potassium dominance. Interaction of precipitation with sediments increases the carbonate concentration relative to chloride.

The Piper plot indicates that runoff chemistry is intermediate between the chemistry of precipitation and sediment water, with $\mathrm{Ca}-\mathrm{HCO}_{3}$ water-type (zone7), as anticipated. This is 
indicated by converging arrows on the Piper plot showing sediment water and precipitation chemistries combining to form runoff.

\subsection{Isotopic Analysis}

The relationship between regional stable isotopes $\left(\delta^{2} \mathrm{H}\right.$ and $\left.\delta^{18} \mathrm{O}\right)$ of runoff and rainfall in the Amargosa Desert region is shown in Figure 5. Lighter waters are often associated with higher altitudes, cooler climatic regimes, or higher latitudes and fall in the lower left portion of the global meteoric water line (GMWL) (Davisson et al., 1999; Izbicki, 2004); heavier waters are often associated with lower altitudes, warmer climatic regimes, or lower latitudes and fall in the upper right portion (Davisson et al., 1999; Izbicki, 2004).

Previous work in southern Nevada showed that rainfall collected in the Amargosa Desert defined a local meteoric water line with the equation $\delta^{2} \mathrm{H}=6.6 * \delta^{18} \mathrm{O}-7.2$ (Ingraham et al.,1991; Benson and Klieforth, 1989), as presented in Figure 5. Most of the precipitation events in southern Nevada that conform to the global MWL have mean isotopic values of less than $9.0 \%$ in $\delta^{18} \mathrm{O}$ and $-60 \%$ in $\delta^{2} \mathrm{H}$ (Davisson et al, 1999). Ingraham et al. (1991) has reported that stable isotope values of modern precipitation in Nevada decrease with increasing latitude and altitude.

Stable isotope composition of runoff and precipitation is shown in Figure 5. Runoff samples have $\delta^{2} \mathrm{H}$ in the range of -114.5 and -77.3 with an average of $-93.5 \%$, while $\delta^{18} \mathrm{O}$ is ranged between -15.8 and -9.3 with an average of $-12.23 \%$. These results show that stable isotope composition of runoff shifts below the GMWL and LMWL and typical mean rainfall values, which suggests short rainfall events and net evaporative concentration of the pore and runoff waters. Stable isotope values for both rainfall and runoff fall close to and below the GMWL, but surface runoff infiltration samples exhibit a broader spread parallel to the GMWL. 


\subsection{Multivariate Statistical Relationships}

The multivariate statistical method applied herein is redundancy analysis (RDA). RDA is similar to canonical correlation analysis, but it is a form of constrained ordination that examines how much of the synthetic variation in one set of (independent) variables explains the variance of another set of (independent) variables (Sen et al., 1986; Schervish, 1987; Liu, 1997; Makarenkov and Legendre, 2002). In this study, RDA was used to explore the complex multivariate relationships in sediment chemistry, precipitation chemistry, and other variables, on the resulting runoff chemistry, as well as, the spatial variation of the chemical constituent concentrations among different sample types. RDA uses principal components analysis (PCA) of the independent variables to form axes which are used to explain the dependent variables. The independent variables were the precipitation and sediment water major chemistry along with elevation, the time since the last runoff causing precipitation event, the amount of precipitation, and the collected sample sizes. The dependent variables were the runoff chemistry.

The first two environmental variable axes formed in the Redundancy Analysis (RDA) are plotted using biplot as shown in Figure 6. The independent variables, which are used to form the axes, are graphed with solid lines where the lower case prefixes "s" and "p" stand for sediment and precipitation, respectively; whereas the dependent runoff variables are graphed with dashed lines and are show without prefixes. The cosine of each arrow direction equals the correlation coefficient of the variable with the first axis and the sine of the arrow direction represents the correlation coefficient with the second axis. Very short arrows, representing little correlation, were deleted from the figure to provide greater clarity. Their variance is not explained by the first two axes so no important information is lost from the graph. 
The overall redundancy analysis explained $41.1 \%$ of the variance in runoff chemistry and was statistically significant at $\mathrm{p}<0.001$. The first axis $(23.8 \%$ of the variance) consists primarily of precipitation chemistry and is dominated by precipitation sulfate and total dissolved solids. The second axis ( $9.9 \%$ of the variance) is dominated by sediment chemistry, especially sediment sulfate and sodium. All precipitation analytes are positively correlated with the first (precipitation) axis and sediment analytes are positively correlated with the second (sediment) axis. Precipitation amount and elevation are positively correlated with first (precipitation) axis and negatively correlated with the second (sediment) axis, but the correlations are not strong.

In the runoff sodium, sulfate, and chloride are positively associated with sediment concentrations of the same ions. Trace metals and fluoride in runoff are clearly associated with precipitation chemistry rather than sediment chemistry. The precipitation chemistry includes total precipitation (wetfall and dryfall). A plausible hypothesis is that the metals arrive predominantly in fine dust. Runoff total dissolved solids and bromide are associated with the first (precipitation chemistry) axis. Consistent with earlier observations, runoff chloride and bromide behave in a dissimilar manner, inconsistent with conservative tracer behavior. Runoff alkalinity, calcium, $\mathrm{pH}$, and silicate are negatively associated with both axes.

\section{Summary and Conclusions}

Ephemeral stream runoff in arid regions derives predominantly from a mixing of precipitation with residual pore waters and water films on near surface sediments. The water chemistry of the runoff derives from this mixture along with any relatively rapid chemical reactions or adsorption/desorption resulting from the addition of the precipitation waters. Small precipitation events in arid environments wet only a shallow depth of sediment prior to essentially complete evaporation and transpiration. In the non-runoff producing storms the water 
has time to react with soil minerals prior to evaporation and weathering and/or ion exchange reactions may occur in the water films. When near complete evaporation of the water occurs the isotopic signature of the water will be lost, but any dissolved ions (and dry-fall) will remain in the shallow soil and sediments along with salt films as pore waters become more concentrated. When surface runoff occurs the new precipitation interacts with the near surface sediments where it mixes with the remaining shallow soil moisture, dissolves some of the precipitated salts in the desiccated soil, and loses/gains some compounds and elements to/from adsorption.

Runoff in the study area is predominantly a calcium bicarbonate water type, and its chemicals were found to follow four patterns, (a) nutrient trend ( $\mathrm{Br}, \mathrm{As}, \mathrm{SO}_{4}{ }^{2-}, \mathrm{PO}_{4}{ }^{3-}$, and $\mathrm{NO}_{3}{ }^{-}$); (b) leached from sediments (Mg, Na); (c) scavenged by sediments (U, F); and (d) conservative behavior (Al, Mn). The main processes that resulted from the current chemical evolution of the runoff are, (a) the dissolution of the precipitation's dryfall increases the carbonate concentration relative to chloride; (b) water-rock interaction related to silicate weathering, and/or ion exchange reactions, produced soluble sodium and dominated the non-carbonate alkalinity; and (c) mineral reactions allowing the sediment to be the net source of some ions.

Multivariate analysis of runoff chemistry indicates that, (a) runoff sodium, sulfate, and chloride are associated with sediment concentrations of the same ions; (b) salinity, and trace metals in runoff are positively associated with the concentration of most dissolved major ions in precipitation; (c) alkalinity, calcium, $\mathrm{pH}$, and silicate are negatively associated with ion concentrations in precipitation and sediments; (d) runoff chloride and bromide behave in a dissimilar manner. Bromide is not appropriate for use as an environmental tracer of water sources in the runoff and its use in other arid region studies should be reevaluated.

\section{Acknowledgements}


Funding for this research was provided by Nye County, NV through a grant from the US Department of Energy office of Civilian Radioactive Waste Management. John Klenke, Roger McRae, and the rest of the Nye County Staff for assistance with sampler construction, installation, and sampling. Dr. David Borrok (Geological Department, UTEP), Dr. Zhuping Sheng (Texas Agrilife Research Center), Dr. William Walker (Civil Engineering Department, UTEP) and their research groups for their help and support with chemical analysis. The Center for Environmental Resource Management of the University of Texas at El Paso for their funding and support.

\section{References}

Ahuja, L.R., 1990. Modeling Soluble Chemical Transfer to Runoff with Rainfall Impact as a Diffusion Process. Soil Sci. Soc. Am. J., 54 (2), pp. 312-321.

Al-Qudah O. M., Woocay A., and Walton J.C. 2015. Ephemeral Stream Chemistry Below the Elevation of Near-zero Net Infiltration, Hydrol. Process., 29 (10), pp. 2385-2401, doi: 10.1002/hyp.10375.

Al-Qudah, O.M., Woocay, A., and Walton, J. 2011. Identification of probable groundwater paths in the Amargosa Desert Vicinity. J. Applied Geochemistry, 26 (4), pp. 565-574. doi:10.1016/j.apgeochem.

Al-Qudah, O.M, Walton, J.C., and Woocay, A., 2010. Tracking the Chemical Footprint of Surface-Runoff Infiltration on Groundwater Recharge in an Arid Region. paper presented at the 36th Annual Radioactive Waste Management Symposium, paper number 10454, vol. 5, p. 3621-3637, Phoenix, AZ.

ASTM D422-63, 2007. Standard Test Method for Particle Size Analysis of Soils. ASTM International, West Conshohocken, Pennsylvania.

ASTM D854-06, 2006. Standard Test Method for Specific Gravity of Soil Solids by Water Pycnometer. ASTM International, West Conshohocken, Pennsylvania.

ASTM D1140-00, 2006.Standard Test Method for Laboratory Amount of Material in Soils Finer than No.200 (75- $\mu \mathrm{m})$ Sieve. ASTM International, West Conshohocken, Pennsylvania.

ASTM D2216-05, 2005. Standard Test Method for Laboratory Determination of Water (Moisture) Content of Soil and Rock by Mass. ASTM International, West Conshohocken, Pennsylvania.

ASTM D4220-95, 2007. Standard Practices for Preserving and Transporting Soil Samples. ASTM International, West Conshohocken, Pennsylvania. 
ASTM D4542, 2007. Standard Test Method for Pore Water Extraction and Determination of the Soluble Salt Content of Soils by Refractometer. ASTM International, West Conshohocken, Pennsylvania.

ASTM D4700-91, 2006. Guide for Soil Sampling from the Vadose Zone. ASTM International, West Conshohocken, Pennsylvania.

Barry, D.A., Sander, G.C., Jomaa, S., Yeghiazarian, L., Steenhuis, T.S., and Selker, J.S., 2013. Solute and Sediment Transport at Laboratory and Field Scale: Contributions of J.-Y. Parlange. Water Resour. Res., 49, pp. 1-27.

Beck, D.A., and Glancy, P.A., 1995. Overview of Runoff of March 11, 1995, in Fortymile Wash and Amargosa River, Southern Nevada. FS-210-95. Fact Sheet, U.S. Geol. Surv.

Benson, L., and Klieforth, H., 1989. Stable Isotopes in Precipitation and Groundwater in the Yucca Mountain Region, Southern Nevada-Paleoclimate Implications, in Peterson, D.H., ed., Aspects of Climate Variability in the Pacific and Western Americas. AGU, Geophysical Monograph, 55, pp. 41-59.

Bowman, R.S., and Rice, R.C., 1985. Chemical Tracers-Their Use in Measuring Deep Percolation Rates. In Proceeding of Third Deep Percolation Symposium, Scottsdale, Arizona.

CEMP (Community Environmental Monitoring Program), 2010. Internet access http://www.cemp.dri.edu/cgi-bin/cemp_stations.pl

Claassen, H.C., 1985. Sources and Mechanisms of Recharge for Groundwater in the WestCentral Amargosa Desert, Nevada - A Geochemical Interpretation, U.S. Geol. Surv., Professional Paper 712-F.

Clescerl, L.S. (Editor), Greenberg, A.E., (Editor), and Eaton, A.D., (Editor), 2000. Standard Methods for the Examination of Water and Wastewater, $\left(20^{\text {th }}\right.$ ed.). American Public Health Association, Washington, DC.

Davis, S.N., Fabryka-Martin, J.T, and Wolfsberg, L.E., 2004. Variations of Bromide in Potable Groundwater in the United States. Groundwater, 42 (6), pp. 902-909.

Davis, S.N., Whittemore, D.O., and Fabryka-Martin, J.T., 1998. Uses of Chloride/Bromide Ratios in Studies of Potable Water. Groundwater, 36 (2), pp. 338-350.

Davisson, M.L., Smith, D.k., Kenneally, J., and Rose, T.P., 1999. Isotope Hydrology of Southern Nevada Groundwater: Stable Isotopes and Radiocarbon. Water Resour. Res., 35 (1), pp. 179-294.

Dettinger, M.D., 1989. Reconnaissance Estimates of Natural Recharge to Desert Basins in Nevada, USA, by Using Chloride-Balance Calculations. J. Hydrol., 106, pp. 55-78.

Dickson, A.G., and Goyet, C., 1994. Handbook of Methods for the Analysis of the Various Parameters of the Carbon Dioxide System in Sea Water, DOE- ORNLCDIAC-74.

DOE-OCRWM (U.S. Department of Energy-Office of Civilian Radioactive Waste Management), 2006. Evaluation of Technical Impact on the Yucca Mountain Project Technical Basis Resulting from Issues Raised by E-Mails of Former Project Participants, DOE/RW-0583, 144 p. 
Drever, J.I., 1997. The Geochemistry of Natural Waters, 3rd ed. Prentice Hall, Upper Saddle River, New Jersey.

Fabryka-Martin, J.T., Turin, H.R., Wolfsberg, A.V., Brenner, D., Dixon, P.R., and Musgrave, J.,1998. Summary Report of Chlorine-36 Studies, Yucca Mountain Site Characterization Project Milestone Report 3782M, Los Alamos, California: Los Alamos National Laboratory.

Fabryka-Martin, J.T., Wolfsberg, A.V., Dixon, P.R., Levy, S.S., Musgrave, J., and Turin H.J.,1997. Summary Report of Chlorine-36 Studies: Systematic Sampling for Chlorine36 in the Exploratory Studies Facility, Los Alamos National Laboratory Report LA13352-MS. Yucca Mountain Site Characterization Project Milestone Report 3783M, Los Alamos, California: Los Alamos National Laboratory.

Fisher, S.G., and Minckley, W.L., 1978. Chemical Characteristics of a Desert Stream in Flash Flood. J. Arid Env., 1, pp. 25-33.

Flint, A.L., Flint, L.E., Bodvarsson ,G.S., Kwicklis, E.M., and Fabryka-Martin, J.T., 2001a. Evolution of the Conceptual Model of Unsaturated Zone Hydrology at Yucca Mountain, Nevada. J. Hydrol., 247, pp. 1-30.

Flint, A.L., Flint, L.E., Kwicklis, E.M., Bodvarsson, G.S., and Fabryka-Martin, J.M., 2001b. Hydrology of Yucca Mountain, Nevada, Reviews of Geophysics. AGU, 39(4), pp. 447470.

Flint, A.L., Flint, L.E., Kwicklis, E.M., Fabryka-Martin, J.T., and Bodvarsson, G.S., 2002. Estimating Recharge at Yucca Mountain, Nevada, USA: Comparison of Methods. Hydrog. J., 10 (1), pp.180-204.

Gao, B., Walter, M.T., Steenhuis, T.S., Hogarth, W.L., and Parlange, J.-Y., 2004. Rainfall Induced Chemical Transport from Soil to Runoff: Theory and Experiments. J. Hydrol., 295(1-4), pp. 291-304.

Gao, B., Walter, M.T., Steenhuis, T.S., Parlange, J.-Y., Richards, B.K., Hogarth, W.L., and Rose, C.W., 2005. Investigating Raindrop Effects on Transport of Sediment and NonSorbed Chemicals from Soil to Surface Runoff. J. Hydrol., 308 (1-4), pp. 313-320.

Guertal, W.R., Flint, A.L., Hofmann, L.L., and Hudson, D.B., 1994. Characterization of a Desert Soil Sequence at Yucca Mountain, NV. Proceeding of the Fifth International High-Level Radioactive Waste Management Conference, Las Vegas, NV, USA; 22-26 May. LaGrange Park, Illinois, American Nuclear Society, p. 2755-2760.

Hem, J.D., 1992.Study and Interpretation of the Chemical Characteristics of Natural Water, USGS Water Supply Paper 2254, (http://pubs.usgs.gov/wsp/wsp2254/), (accessed September, 2010).

Hevesi, J. A., Flint, A. L., and Flint, L. E., 2003. Simulation of Net Infiltration and Potential Recharge Using a Distributed Parameter Watershed Model for the Death Valley Region, Nevada and California. U.S. Geol. Surv. Water-Resour. Invest. Rep. 03-4090, Sacramento, CA. 
Hevesi, J. A., Flint, A. L., and Flint, L. E., 2002. Preliminary Estimates of Spatially Distributed Net Infiltration and Recharge for the Death Valley Region, Nevada-California, U.S. Geol. Surv. Rep. 02-4010.

Ingraham, N.L., Lyles, B.F., Jacobson, R.L., and Hess, J.W., 1991. Stable Isotope Study of Precipitation and Spring Discharge in Southern Nevada, J. Hydro., 125, pp. 243-258.

Izbicki, J. A., 2004. Source and Movement of Ground Water in the Western Part of the Mojave Desert, Southern California, USA. U.S. Geol. Surv. Water-Resour. Invest. Rep. 03-4313.

Johnson, M.J., Mayers, C.J., Garcia, C.A., and Andraski, B.J., 2007. Selected Micrometeorological, Soil Moisture, and Evapotranspiration Data at Amargosa Desert Research Site in Nye County near Beatty, Nevada, 2001-2005: U.S. Department of the Interior, U.S. Geol. Surv.

Katz, B.G., Eberts, S.M., and Kauffman, L.J., 2011.Using Cl/Br Ratios and other Indicators to Assess Potential Impacts on Groundwater Quality from Septic Systems: A Review and Examples from Principle Aquifers in the United States, J. Hydrol., 397, pp. 151-166.

Kwicklis, E., Meijer, A., and Fabryka-Martin, J.T., 2003.Geochemical Inverse Model of Groundwater Mixing and Chemical Evolution in the Yucca Mountain Area, International High- Level Radioactive Waste Management Conference, Las Vegas, Nevada. La Grange Park, Illinois: American Nuclear Society.

Liu, Q., 1997. Variation Partitioning by Partial Redundancy Analysis (RDA). Environmetrics 8, pp. 75-85.

Makarenkov, V., and Legendre, P., 2002. Nonlinear Redundancy Analysis and Canonical Correspondence Analysis Based on Polynomial Regression. Ecology, 83 (4), pp. 11461161.

Montazer, P., and Wilson, W. E., 1984. Conceptual Hydrologic Model of Flow in the Unsaturated Zone, Yucca Mountain, NV. U.S. Geol. Surv. Rep. 84-4344.

Nativ, R., Adar, E., Dahan, O., and Nissim, I., 1997. Water Salinization in Arid RegionsObservations from the Negev Desert, Israel. J. Hydrol., 196, pp. 271-296.

Neal, C., Margaret, N., Hughes, S., Wickham, H., Hill, L., and Harman, S., 2007. Bromine and Bromide in Rainfall, Cloud, Stream and Groundwater in the Plynlimon Area of MidWales, Hydrology and Earth System Sciences, 11(1), pp. 301-312.

Parkhurst, D.L., and Appelo, C.A.J., 1999. User's Guide to PHREEQC (Version 2): a Computer Program for Speciation, Batch-Reaction, One-Dimensional Transport, and Inverse Geochemical Calculations: U.S. Geol. Surv. Water-Resour. Invest. Rep. 99-4259, 310 p.

Reeve, A.S., 2002. The Migration of a Sodium Bromide Tracer in a Large Maine Peatland. In Proceeding of GSA Abstracts with Programs 34(6), 420 p.

Russell, C. E., Mizell, S. A., and Minor, T. B., 2007. Estimation of Groundwater Recharge in Steptoe Valley, Nevada, by the Elevation-Dependent Chloride Mass-Balance Approach. DRI Publication no. 41241, Las Vegas and Reno, Nevada, 53 p.

Russell, C.E., and T. Minor, 2002. Reconnaissance estimates of recharge based on an elevationdependent chloride mass-balance approach, Nevada Operations Office National Nuclear 
Security Administration, U.S. DOE, Rep. DOE/NV/11508-37, Publ. no.45164, Las Vegas, Nevada.

Savard, C. S., 1998. Estimated Groundwater Recharge from Stream-Flow in Fortymile Wash Near Yucca Mountain, Nevada. U.S. Geol. Surv. Rep., 97-4273.

Schervish, M.J., 1987. A Review of Multivariate Analysis. Statistical Science 2 (4), pp, 396-413.

Sen, P.K., Anderson, T.W., Arnold, S.F., Eaton, M.L., Giri, N.C., Gnanadesikan, R., Kendall, M. G., and Kshirsagar, A. M., 1986. Review: Contemporary Textbooks on Multivariate Statistical Analysis: A Panoramic Appraisal and Critique. Journal of the American Statistical Association 81 (394), pp. 560-564.

SNL (Sandia National Laboratories), 2008. Total System Performance Assessment for the Yucca Mountain Site, DOC. 20080312.0001/ MDL-WIS-PA-000005 REV00.

Steenhuis, T.S., Boll, J., Shalit, G., Selker, J.S., and Merwin, I. A., 1994. A Simple Equation for Predicting Preferential Flow Solute Concentrations. J. Environ. Qual., 23 (5), pp. 10581064.

Stetzenbach, K.J., and Brandt, A., 2007. Precipitation Monitoring at Yucca Mountain, Publications (YM), Paper 10, http://digitalcommons.library.unlv.edu/yucca_mtn_pubs/10

Stetzenbach, K.J., Hodge, V.F., Guo, C., Farnham, I.M., and Johannesson, K.H., 2001. Geochemical and Statistical Evidence of Deep Carbonate Groundwater within Overlying Volcanic Rock Aquifers/Aquitards of Southern Nevada, USA. J. Hydrol., 243, pp. 254271

Wallach, R., 1991). Runoff contamination by Soil Chemicals: Time Scale Approach. Water Resour. Res., 27 (2), pp. 215-223.

Wallach, R., and van Genuchten, M.Th., 1990. A Physically Based Model for Predicting Solute Transfer from Soil Solution to Rainfall-Induced Runoff Water. Water Resour. Res., 26 (9), pp. 2119-2126.

Walter, M.T., Gao, B., and Parlange, J.-Y., 2007. Modeling Soil Solute Release into Runoff with Infiltration. J. Hydrol., 347 (3-4), pp. 430-437.

White, A.F., 1979. Geochemistry of Groundwater Associated with Tuffaceous Rocks, Oasis Valley, Nevada, U.S. Geol. Surv., Professional Paper 712-E, 25 p.

Zhang, X.C., Norton, D., and Nearing, M. A., 1999, Coupling Mixing Zone Concept with Convection-Diffusion Equation to Predict Chemical Transfer to Surface Runoff, Trans. ASAE, 42 (4), pp. 987-994. 


\section{Figure Captions}

Figure 1. Digital elevation model (DEM) of the Amargosa Desert region, NV, shows the location of the site locations as well as the lysimeters (black diamonds). ASL means above sea level.

Figure 2. Photographic sequence of the lysimeter and sediment methods show: (a) a polyethylene tubing (6.35-mm outer diameter) threaded through a hole made at $25 \mathrm{~mm}$ below the top edge of the 9.5-liter bucket and glued to the bottom of the bucket; (b) partially filled lysimeter with washed silica sand; (c) lysimeter installed at $25-50 \mathrm{~mm}$ below the undisturbed surface; (d) fully filled lysimeter with washed silica sand after emplacement, and the tube is exiting the device to provide access to the inside of the lysimeter; (e) location of two lysimeter after emplacement at site S-8A2; (f) runoff in the Fortymile Wash after a storm event occurred in December, 2010; (g and h) Fortymile Wash after a storm event occurred in December, 2010 and shows the lysimeters burred under alluvium materials that were transported and accumulated by the runoff ; (i) runoff sampling process; (j) field measurement of alkalinity, $\mathrm{pH}$, and $\mathrm{EC}$ for precipitation and runoff samples; (k) sediment samples; and (l) leaching sediment to obtain its chemical characteristics.

Figure 3. Median concentration of the chemical elements of sediment water and runoff (lysimeter water) normalized by sample chloride and precipitation contents of that element. When sediment waters $>$ lysimeter waters $>1$ (i.e., precipitation) it is leached behavior; when sediment waters $>1$ and lysimeter waters < 1 (i.e., precipitation \& sediments > lysimeter) it is nutrient behavior; when $1>$ lysimeter waters $>$ sediment waters (i.e., precipitation $>$ runoff $>$ sediments) it is scavenged behavior; and it is conservative behavior: when precipitation $\approx$ runoff and is taken as the default behavior whenever none of the other behaviors are statistically significant $(p>0.05)$.

Figure 4. Piper diagram for precipitation, runoff, and sediment water samples shows water chemical characteristics with chemical type definition. Symbol size is proportional to TDS content. The diamond shape in the middle reflects the hydrochemical facies presented by the lower triangles. The black disconnected arrows on the Piper plot showing sediment water and precipitation chemistries combining to form runoff.

Figure 5. Water stable isotopes of runoff and rainfall. Rainfall stable isotopes data was obtained from Ingraham et al. (1991) and Benson and Klieforth, (1989). GMWL, global meteoric water line; LMWL, local meteoric water line.

Figure 6. Biplot graph shows the first two environmental variable axes of the redundancy analysis. Redundancy analysis used principal components analysis of the independent variables (precipitation and sediment water major chemistry along with elevation and the time since the last runoff causing precipitation event) to form axes which are used to explain the dependent variables (runoff) chemical evolution. Where "p" is precipitation and "s" is sediment water. Dashed lines represent runoff, and solid lines represent independent variable. 


\section{Table lists}

Table 1. Basic statistics of the mean chemical analysis results of the major elements and some of trace metals.

Table 2. Ratios of the major elements (equivalent ratios)

Table 3. PHREEQC major saturation indices (SI) average values for runoff and sediment water 
TABLES

Table 1. Basic statistics of the mean chemical analysis results of the major elements and some of trace metals*

\begin{tabular}{|c|c|c|c|c|c|c|c|c|c|c|c|c|c|c|c|c|c|c|c|c|c|}
\hline \multirow[b]{2}{*}{ Sample type } & \multirow[b]{2}{*}{$\begin{array}{l}\text { Basic } \\
\text { statistics }\end{array}$} & \multirow[b]{2}{*}{ TDS } & \multicolumn{6}{|c|}{ Anions } & \multicolumn{4}{|c|}{ Cations } & \multicolumn{9}{|c|}{ Trace metals } \\
\hline & & & $\begin{array}{c}\text { T. Alk } \\
\text { as } \\
\mathrm{CaCO}_{3}{ }^{\mathrm{a}}\end{array}$ & $\mathrm{Cl}^{-}$ & $\mathrm{SO}_{4}^{2-}$ & $\mathrm{NO}_{3}^{-}$ & $\mathrm{Br}^{-}$ & $\mathrm{F}^{-}$ & $\mathrm{Ca}^{2+}$ & $\mathrm{Mg}^{2+}$ & $\mathrm{K}^{+}$ & $\mathrm{Na}^{+}$ & $\mathrm{Al}$ & As & $\mathrm{Cu}$ & $\mathrm{Fe}$ & Cs & $\mathrm{Li}$ & $\mathrm{Sr}$ & $\mathrm{U}$ & $\mathrm{Zn}$ \\
\hline \multirow{6}{*}{$\begin{array}{l}\text { Sediment } \\
\text { water before } \\
\text { storm events } \\
\left(\mathrm{n}^{\mathrm{b}}=70\right)\end{array}$} & Median & 164 & 158 & 1.4 & 3.4 & 4.8 & 0.2 & 0.04 & 39.7 & 2.3 & 9.6 & 4.9 & $\begin{array}{l}0.07 \\
\end{array}$ & 0.01 & 0.08 & 0.08 & 0.008 & 0.006 & 0.1 & $4 \mathrm{E}-5$ & 0.003 \\
\hline & Mean & 193 & 180 & 3.3 & 8.8 & 7.2 & 3.4 & 0.09 & 43.8 & 2.9 & 10.2 & 12.1 & 0.2 & 0.01 & 0.09 & 0.2 & 0.01 & 0.01 & 0.1 & 0.001 & 0.008 \\
\hline & Minimum & 60 & 55 & 0.4 & 0.3 & 1.9 & 0.1 & 0.03 & 9.2 & 0.5 & 4.3 & 2 & 0.02 & $3 \mathrm{E}-4$ & 0.01 & 0.02 & $4 \mathrm{E}-4$ & 0.002 & 0.01 & $4 \mathrm{E}-5$ & $1 \mathrm{E}-4$ \\
\hline & Maximum & 1018 & 892 & 15.8 & 88.7 & 60.9 & 35.8 & 1.4 & 253 & 25.2 & 30.5 & 76.8 & 5.8 & 0.04 & 0.2 & 3.6 & 0.09 & 0.09 & 0.9 & 0.01 & 0.25 \\
\hline & Std.Dev. & 127 & 103 & 3.8 & 14 & 7.5 & 5.8 & 0.2 & 29.5 & 2.7 & 5 & 15.7 & 0.7 & 0.007 & 0.03 & 0.4 & 0.01 & 0.01 & 0.1 & 0.002 & 0.03 \\
\hline & \multicolumn{21}{|c|}{ Median ionic dominance $(\mathrm{meq} / \mathrm{l}): \mathrm{HCO}_{3}>\mathrm{Na}>\mathrm{Ca} \geq \mathrm{K}>\mathrm{Mg}>\mathrm{NO}_{3}>\mathrm{Br}>\mathrm{SO}_{4}>\mathrm{Cl}>\mathrm{F}$} \\
\hline \multirow{6}{*}{$\begin{array}{l}\text { Precipitation } \\
(\mathrm{n}=45)\end{array}$} & Median & 29 & 12 & 2 & 3.7 & 1.6 & 0.4 & 0.2 & 4.4 & 0.6 & 0.7 & 1.3 & 0.01 & 0.007 & 0.004 & 0.002 & 0.006 & 0.003 & 0.04 & $4 \mathrm{E}-4$ & 0.007 \\
\hline & Mean & 45 & 14 & 2.7 & 4.5 & 2.0 & 0.4 & 0.4 & 5 & 0.6 & 0.8 & 1.6 & 0.02 & 0.007 & 0.003 & 0.005 & 0.008 & 0.004 & 0.04 & 0.001 & 0.01 \\
\hline & Minimum & 7 & 3 & 0.6 & 0.1 & 0.1 & 0.2 & 0.05 & 0.6 & 0.1 & 0.05 & 0.4 & 0.004 & $3 \mathrm{E}-4$ & $7 \mathrm{E}-4$ & $3 \mathrm{E}-4$ & 0.001 & $3 \mathrm{E}-4$ & 0.007 & $5 \mathrm{E}-5$ & $9 \mathrm{E}-4$ \\
\hline & Maximum & 223 & 25 & 6.8 & 11.5 & 6.2 & 0.6 & 1.3 & 12 & 1.8 & 2 & 4 & 0.05 & 0.03 & 0.008 & 0.03 & 0.03 & 0.03 & 0.2 & 0.005 & 0.05 \\
\hline & Std.Dev. & 53 & 7 & 1.7 & 3.3 & 1.8 & 0.07 & 0.3 & 2.7 & 0.4 & 0.5 & 1 & 0.01 & 0.005 & 0.002 & 0.006 & 0.008 & 0.006 & 0.03 & 0.001 & 0.01 \\
\hline & \multicolumn{21}{|c|}{ Median ionic dominance (meq/l): $\mathrm{HCO}_{3}>\mathrm{C}>>\mathrm{SO}_{4}>\mathrm{Cl} \geq \mathrm{Na}>\mathrm{Mg}>\mathrm{NO}_{3}>\mathrm{K}>\mathrm{F}>\mathrm{Br}$} \\
\hline \multirow{6}{*}{$\begin{array}{l}\text { Sediment } \\
\text { water after } \\
\text { storm events } \\
(\mathrm{n}=112)\end{array}$} & Median & 95 & 109 & 0.9 & 1.5 & 2.6 & 0.2 & 0.04 & 18.1 & 1 & 5.5 & 4.4 & 0.05 & 0.005 & 0.008 & 0.01 & 0.004 & 0.005 & 0.07 & $4 \mathrm{E}-5$ & 0.002 \\
\hline & Mean & 114 & 117 & 2.1 & 4.6 & 3.7 & 1.7 & 0.05 & 18.4 & 1.1 & 5.7 & 10 & 0.1 & 0.006 & 0.01 & 0.03 & 0.007 & 0.008 & 0.08 & $6 \mathrm{E}-4$ & 0.003 \\
\hline & Minimum & 48 & 35.5 & 0.3 & 0.2 & 0.4 & 0.1 & 0.01 & 4.6 & 0.2 & 1.7 & 2 & 0.01 & $2 \mathrm{E}-4$ & $1 \mathrm{E}-4$ & $1 \mathrm{E}-4$ & $2 \mathrm{E}-4$ & 0.001 & 0.008 & $2 \mathrm{E}-5$ & $1 \mathrm{E}-4$ \\
\hline & Maximum & 455 & 219 & 9 & 52.5 & 26.2 & 15.1 & 0.7 & 49 & 4 & 16.9 & 54.5 & 1.6 & 0.02 & 0.05 & 0.7 & 0.04 & 0.04 & 0.5 & 0.008 & 0.04 \\
\hline & Std.Dev. & 56 & 32.3 & 2.4 & 8.5 & 3.9 & 2.9 & 0.07 & 8.4 & 0.6 & 2.5 & 11.6 & 0.2 & 0.004 & 0.009 & 0.07 & 0.007 & 0.007 & 0.07 & 0.001 & 0.004 \\
\hline & \multicolumn{21}{|c|}{ Median ionic dominance (meg/l): $\mathrm{HCO}_{3}>\mathrm{Ca}>\mathrm{Na}>\mathrm{K}>\mathrm{Mg}>\mathrm{NO}_{3}>\mathrm{Br}>\mathrm{SO}_{4}>\mathrm{Cl}>\mathrm{F}$} \\
\hline \multirow{6}{*}{$\begin{array}{l}\text { Runoff } \\
(\mathrm{n}=167)\end{array}$} & Median & 142 & 69 & 8 & 7.9 & 1.6 & 0.2 & 0.3 & 22 & 3.7 & 6 & 7.1 & 0.2 & 0.003 & 0.004 & 0.07 & 0.04 & 0.02 & 0.14 & 0.001 & 0.008 \\
\hline & Mean & 246 & 104 & 10 & 15.4 & 7.3 & 0.4 & 0.4 & 25.4 & 5.5 & 9.8 & 18.2 & 0.2 & 0.007 & 0.007 & 0.09 & 0.07 & 0.02 & 0.17 & 0.003 & 0.01 \\
\hline & Minimum & 51 & 33 & 1.9 & 1.5 & 0.02 & 0.2 & 0.05 & 9.3 & 1.2 & 2.8 & 1.7 & 0.02 & 0.001 & 0.001 & 0.005 & 0.01 & 0.008 & 0.04 & $2 \mathrm{E}-4$ & 0.005 \\
\hline & Maximum & 814 & 354 & 30 & 88 & 48 & 1.1 & 1.2 & 86.1 & 12.2 & 29.7 & 74 & 0.6 & 0.05 & 0.03 & 0.3 & 0.3 & 0.03 & 0.4 & 0.01 & 0.03 \\
\hline & Std.Dev. & 210 & 81 & 11.6 & 20.5 & 13 & 0.3 & 0.3 & 15.3 & 5 & 8.1 & 22.1 & 0.1 & 0.01 & 0.007 & 0.07 & 0.06 & 0.007 & 0.1 & 0.004 & 0.008 \\
\hline & \multicolumn{21}{|c|}{ Median ionic dominance (meq/l): $\mathrm{HCO}_{3}>\mathrm{Ca}>\mathrm{Na}>\mathrm{Mg}>\mathrm{Cl}>\mathrm{SO}_{4}>\mathrm{K}>\mathrm{NO}_{3}>>\mathrm{Br}>\mathrm{F}$} \\
\hline
\end{tabular}


Table 2. Ratios of the major elements (equivalent ratios)

\begin{tabular}{|c|c|c|c|c|c|}
\hline Sample type & $\mathrm{Na}^{+} / \mathrm{Cl}^{-}$ & $\left(\mathrm{Alk}-\left(\mathrm{Ca}^{2+}+\mathrm{Mg}^{2+}\right)\right) / \mathrm{Alk}$ & $\mathrm{Ca}^{2+} / \mathrm{Na}^{+}$ & $\mathrm{Cl}^{-} / \mathrm{Br}^{-}$ & $\mathrm{Na}^{+} / \mathrm{K}^{+}$ \\
\hline *Seawater & $0.86^{\mathrm{a}, \mathrm{e}}$ & - & $0.01^{\mathrm{e}}$ & $640^{\mathrm{a}, \mathrm{b}, \mathrm{e}}$ & $47^{\mathrm{a}, \mathrm{e}}$ \\
\hline Precipitation & -- & -- & -- & $220^{\mathrm{c}, \mathrm{d}}$ & $10^{\mathrm{a}}$ \\
\hline Sediment water & -- & -- & -- & $133^{\mathrm{c}, \mathrm{d}}$ & -- \\
\hline Runoff & -- & -- & -- & $20-225^{\mathrm{c}}$ & -- \\
\hline \multicolumn{6}{|c|}{ Sediment water before storm events } \\
\hline range & 0.2 to 92.4 & -0.3 to 0.8 & 0.3 to 35.2 & 0.06 to 251 & 0.3 to 11 \\
\hline mean & 9.8 & 0.2 & 9.2 & 29.5 & 2.0 \\
\hline \multirow{2}{*}{$\%$ of samples } & $90 \%>1$ & $82 \%>0$ & $91 \%>1$ & $86 \%<100$ & $98 \%<10$ \\
\hline & $10 \%<1$ & $18 \%<0$ & $9 \%<1$ & $14 \%>100$ & $2 \%(10-47)$ \\
\hline \multicolumn{6}{|l|}{ Precipitation } \\
\hline mean & 0.8 & -0.2 & 5.0 & 11.2 & 5.0 \\
\hline \multirow[t]{2}{*}{$\%$ of samples } & $15 \%>1$ & $33 \%>0$ & $97 \%>1$ & $100 \%<110$ & $90 \%<10$ \\
\hline & $85 \%<1$ & $67 \%<0$ & $3 \%<1$ & & $10 \%(10-47)$ \\
\hline \multicolumn{6}{|c|}{ Sediment water after storm events } \\
\hline range & 0.5 to 75.2 & -0.7 to 0.9 & 0.2 to 12.4 & 0.1 to 143 & 0.6 to 13.5 \\
\hline mean & 11.5 & 0.5 & 4.7 & 18.9 & 3.0 \\
\hline \multirow[t]{2}{*}{$\%$ of samples } & $96 \%>1$ & $98 \%>0$ & $79 \%>1$ & $96 \%<100$ & $96 \%<10$ \\
\hline & $4 \%<1$ & $2 \%<0$ & $21 \%<1$ & $4 \%>100$ & $4 \%(10-47)$ \\
\hline \\
\hline mean & 4.7 & -0.03 & 4.6 & 68.5 & 3.4 \\
\hline \multirow[t]{2}{*}{$\%$ of samples } & $66 \%>1$ & $67 \%>0$ & $85 \%>1$ & $38 \%(20-225)$ & $89 \%<10$ \\
\hline & $19 \%<1$ & $33 \%<0$ & $15 \%<1$ & $50 \%<20$ & $11 \%(10-47)$ \\
\hline
\end{tabular}

* First row consists of literature values. ${ }^{\text {a }}$ (Nativ et al., 1997); ${ }^{\text {b }}$ (Katz et al., 2011); ${ }^{\mathrm{c}}$ (Davis et al., 2004, 1998); ${ }^{\mathrm{d}}$ (Fabryka-Martin et al. 1998, 1997); (Dickson and Goyet, 1994). 
Table 3. PHREEQC major saturation indices (SI) average values for runoff and sediment water

\begin{tabular}{llccc}
\hline \hline \multicolumn{1}{c}{ Phase } & \multicolumn{1}{c}{ Formula } & $\begin{array}{c}\text { (SI) Sediment } \\
\text { water before } \\
\text { storm events }\end{array}$ & $\begin{array}{c}\text { (SI) Sediment } \\
\text { water after } \\
\text { storm events }\end{array}$ & (SI) Runoff \\
\cline { 2 - 4 } Albite & $\mathrm{NaAlSi}_{3} \mathrm{O}_{8}$ & -2.92 & -4.01 & -1.77 \\
Anorthite & $\mathrm{CaAl}_{2} \mathrm{Si}_{2} \mathrm{O}_{8}$ & -2.02 & -3.37 & -0.41 \\
Ca-Montmorillonite & $\mathrm{Ca}_{0.165} \mathrm{Al}_{2.33} \mathrm{Si}_{3.67} \mathrm{O}_{10}(\mathrm{OH})_{2}$ & -0.39 & -1.2 & 4.22 \\
Calcite & $\mathrm{CaCO}_{3}$ & 1.26 & 0.41 & 0.16 \\
Celestite & $\mathrm{SrSO}_{4}$ & -3.55 & -3.95 & -3.13 \\
Chlorite(14A) & $\mathrm{Mg}_{5} \mathrm{Al}_{2} \mathrm{Si}_{3} \mathrm{O}_{10}(\mathrm{OH})_{8}$ & 4.31 & -2.01 & 1.97 \\
Chrysotile & $\mathrm{Mg}_{3} \mathrm{Si}_{2} \mathrm{O}_{5}(\mathrm{OH})_{4}$ & 0.14 & -3.84 & -2.48 \\
Dolomite & $\left.\mathrm{CaMg}_{2} \mathrm{CO}_{3}\right)_{2}$ & 1.71 & -0.04 & 0.08 \\
Fluorite & $\mathrm{CaF}_{2}$ & -3.28 & -4.05 & -2.56 \\
Gypsum & $\mathrm{CaSO}_{4}: 2 \mathrm{H}_{2} \mathrm{O}$ & -2.78 & -3.32 & -2.57 \\
Hydroxyapatite & $\mathrm{Ca}_{5}\left(\mathrm{PO}_{4}\right)_{3} \mathrm{OH}$ & 6.91 & 4.02 & 4.82 \\
Illite & $\mathrm{K}_{0.6} \mathrm{Mg}_{0.25} \mathrm{Al}{ }_{2.3} \mathrm{Si}_{3.5} \mathrm{O}_{10}(\mathrm{OH})_{2}$ & 0.07 & -1.2 & 4.07 \\
K-feldspar & $\mathrm{KAlSi}_{3} \mathrm{O}_{8}$ & -0.68 & -1.93 & 1.55 \\
Melanterite & $\mathrm{FeSO}_{4}: 7 \mathrm{H}_{2} \mathrm{O}$ & -20.08 & -20.26 & -9.5 \\
Rhodochrosite & $\mathrm{MnCO}_{3}$ & 0.52 & -0.53 & 0.2 \\
Sepiolite & $\mathrm{Mg}_{2} \mathrm{Si}_{3} \mathrm{O}_{7.5} \mathrm{OH}: 3 \mathrm{H}_{2} \mathrm{O}$ & -1.15 & -4.22 & -1.82 \\
Talc & $\mathrm{Mg}_{3} \mathrm{Si}_{4} \mathrm{O}_{10}(\mathrm{OH})_{2}$ & 2.67 & -1.78 & 1.27 \\
Willemite & $\mathrm{Zn}_{2} \mathrm{SiO}_{4}$ & -1.65 & -2.8 & -0.35 \\
\hline \hline
\end{tabular}




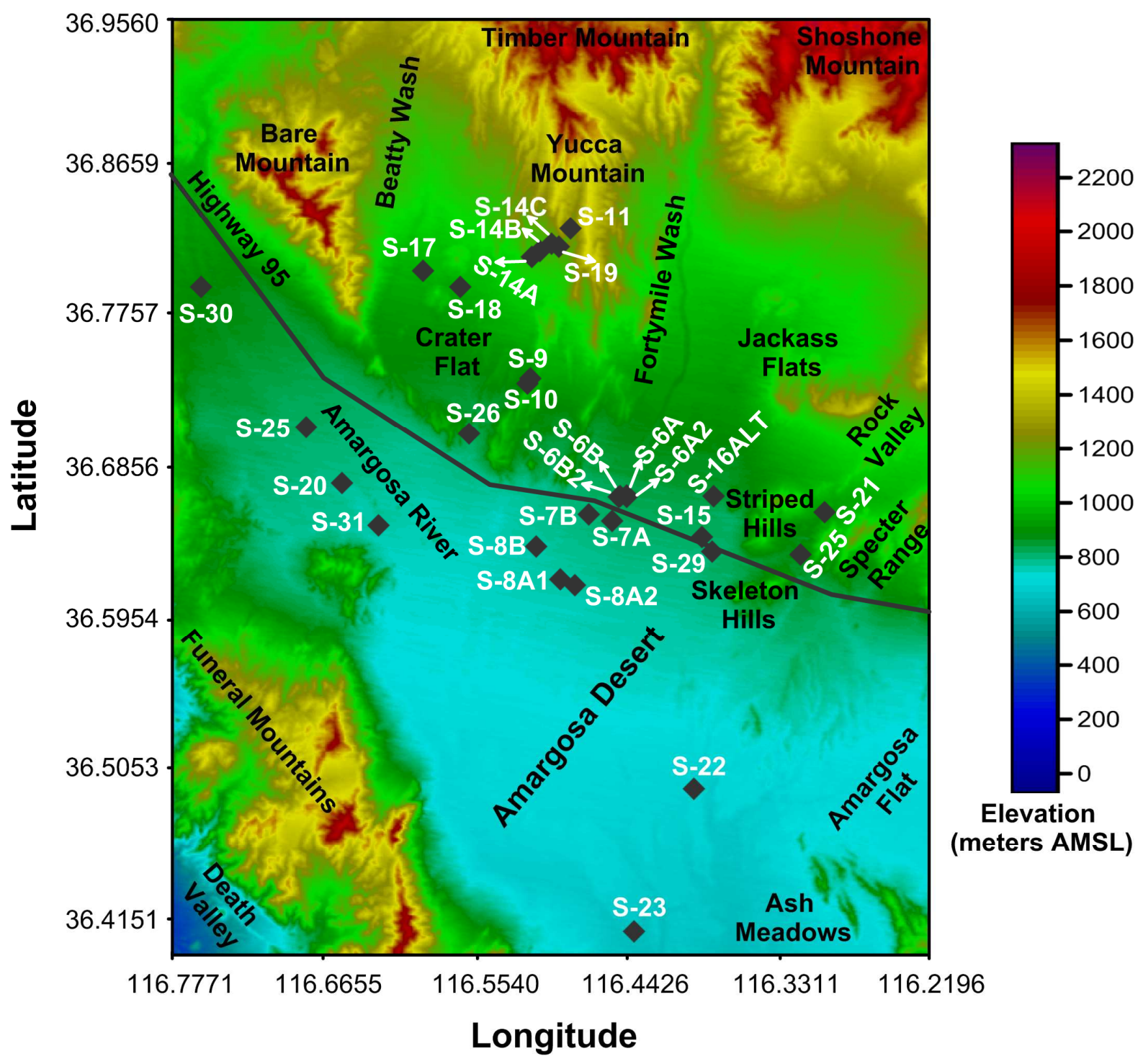

Fig 1 

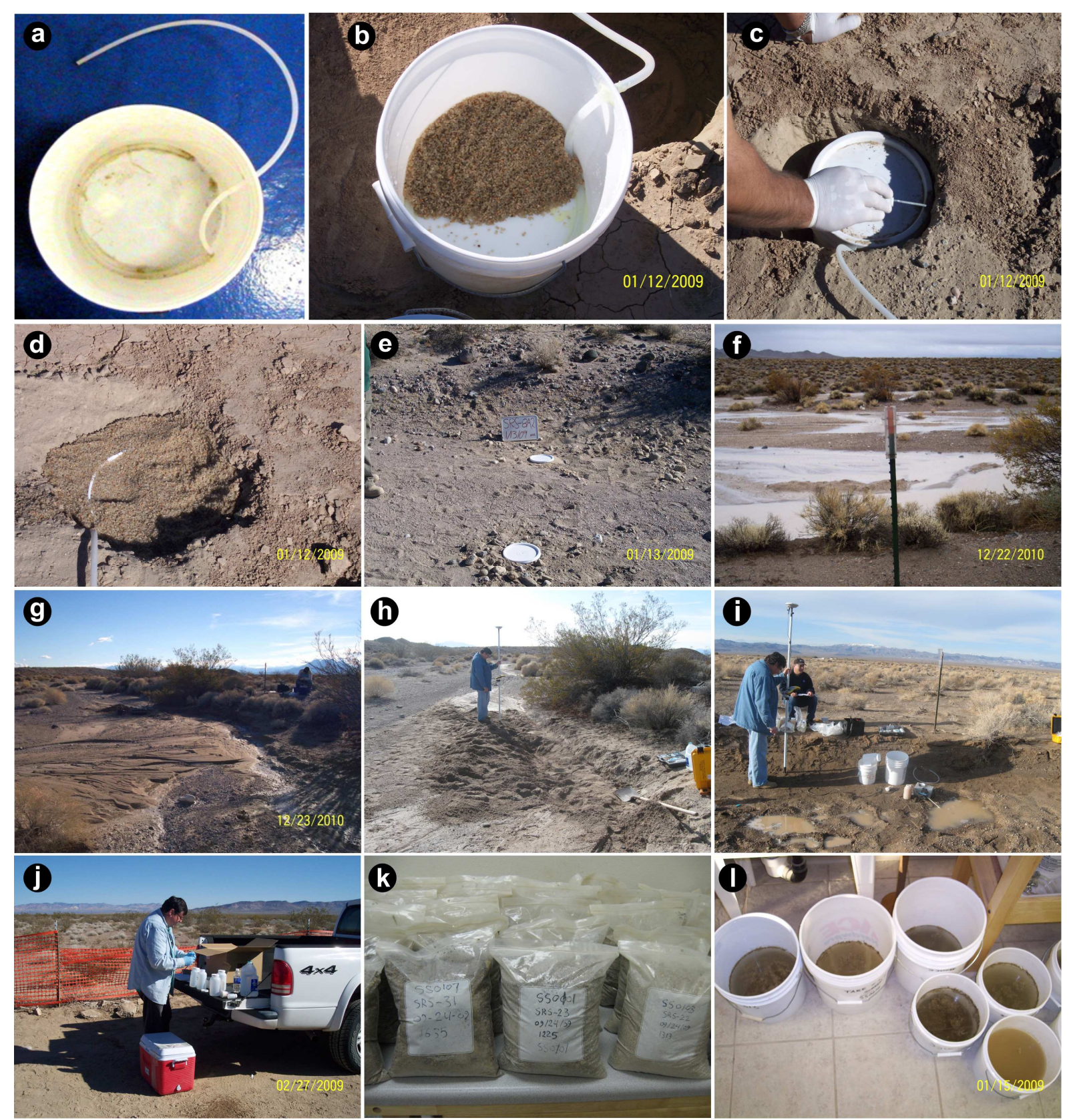

Fig 2 


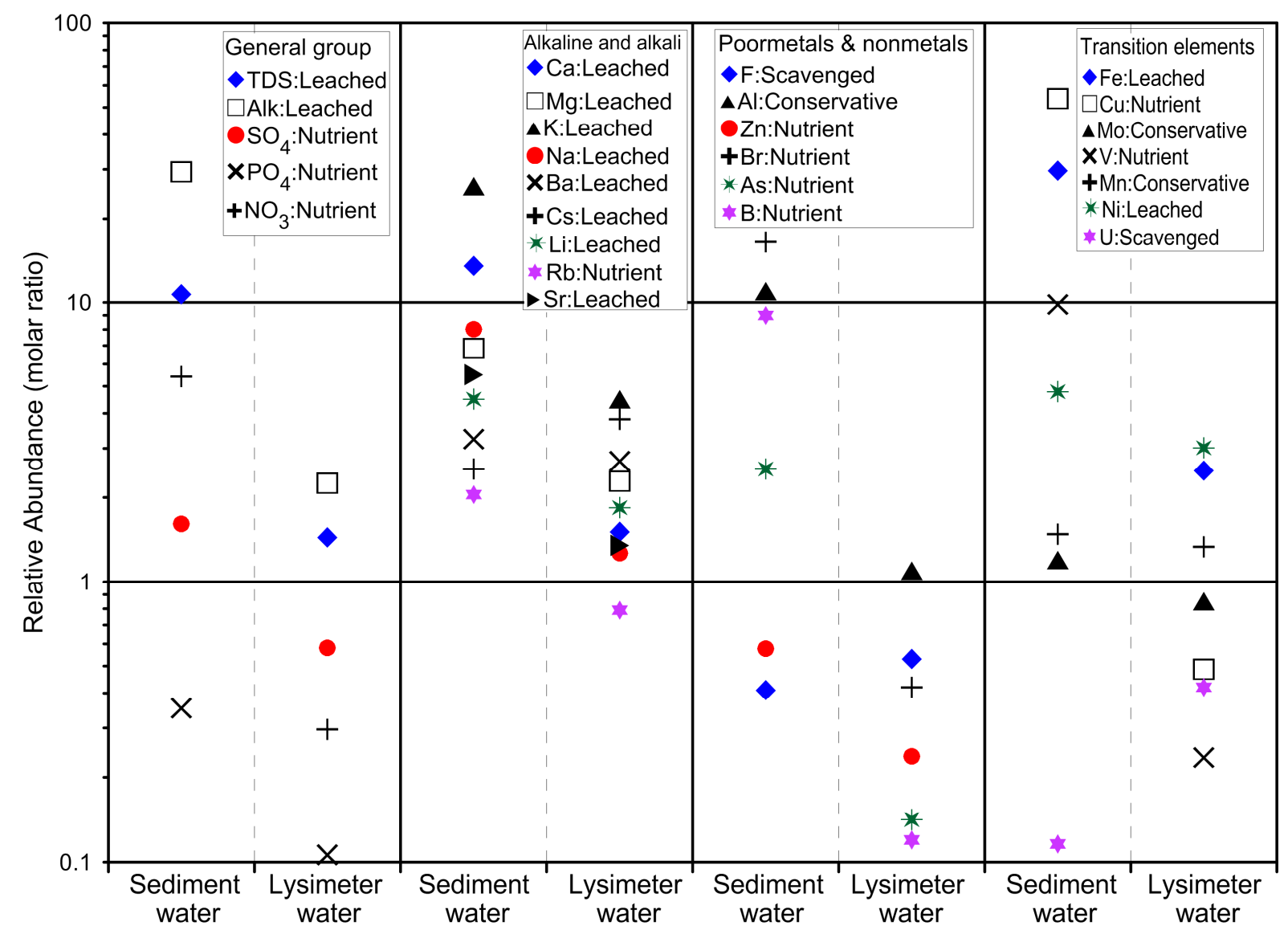

Fig 3 
+ Precipitation

Sediment water, pre-storms

Sediment water, post-storms

$\star$ Runoff

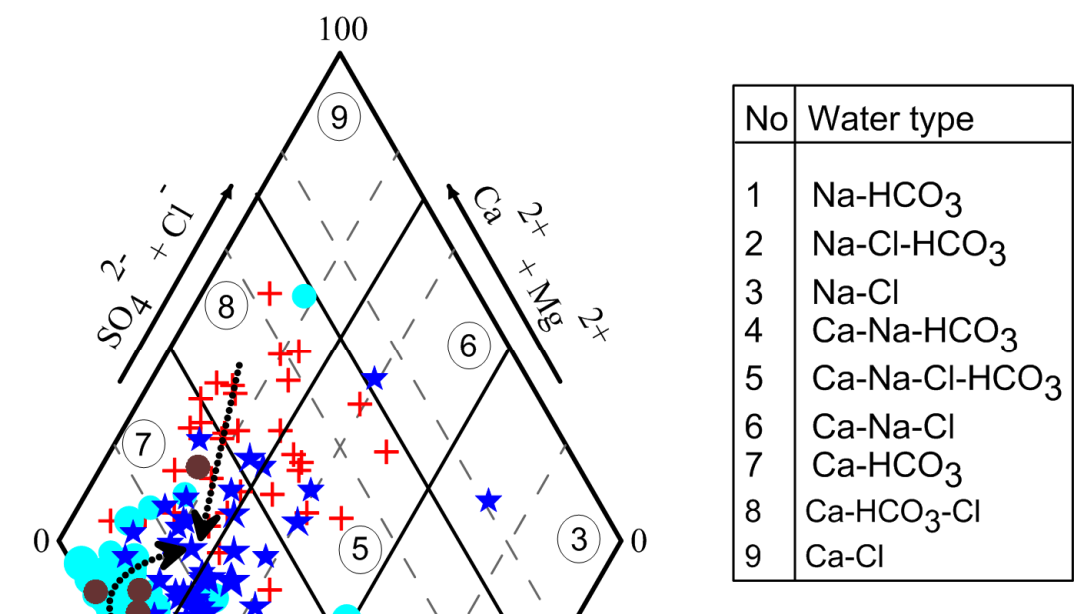

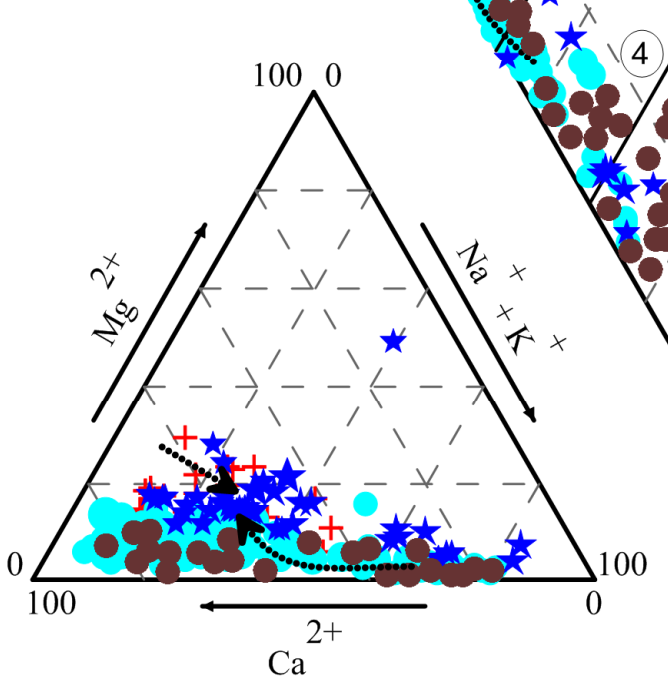

CATIONS

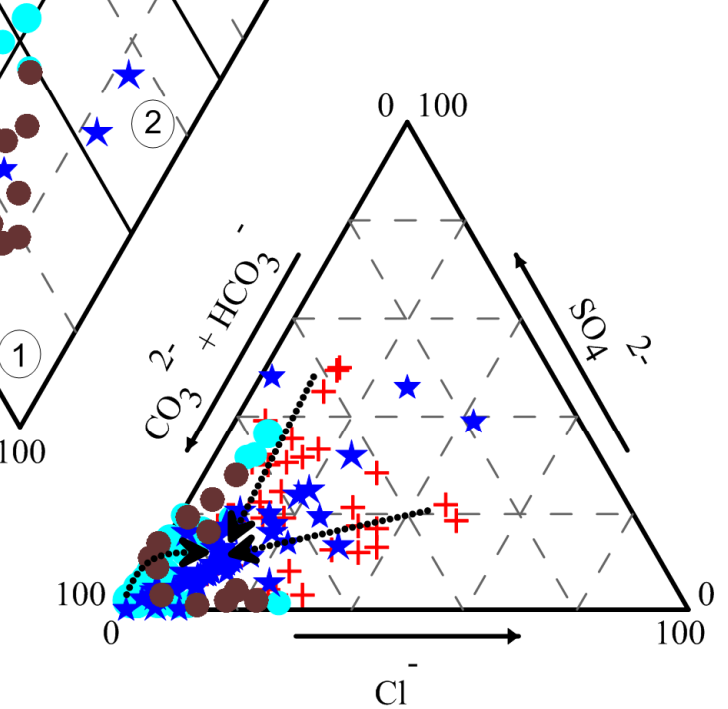

ANIONS

Fig 4 


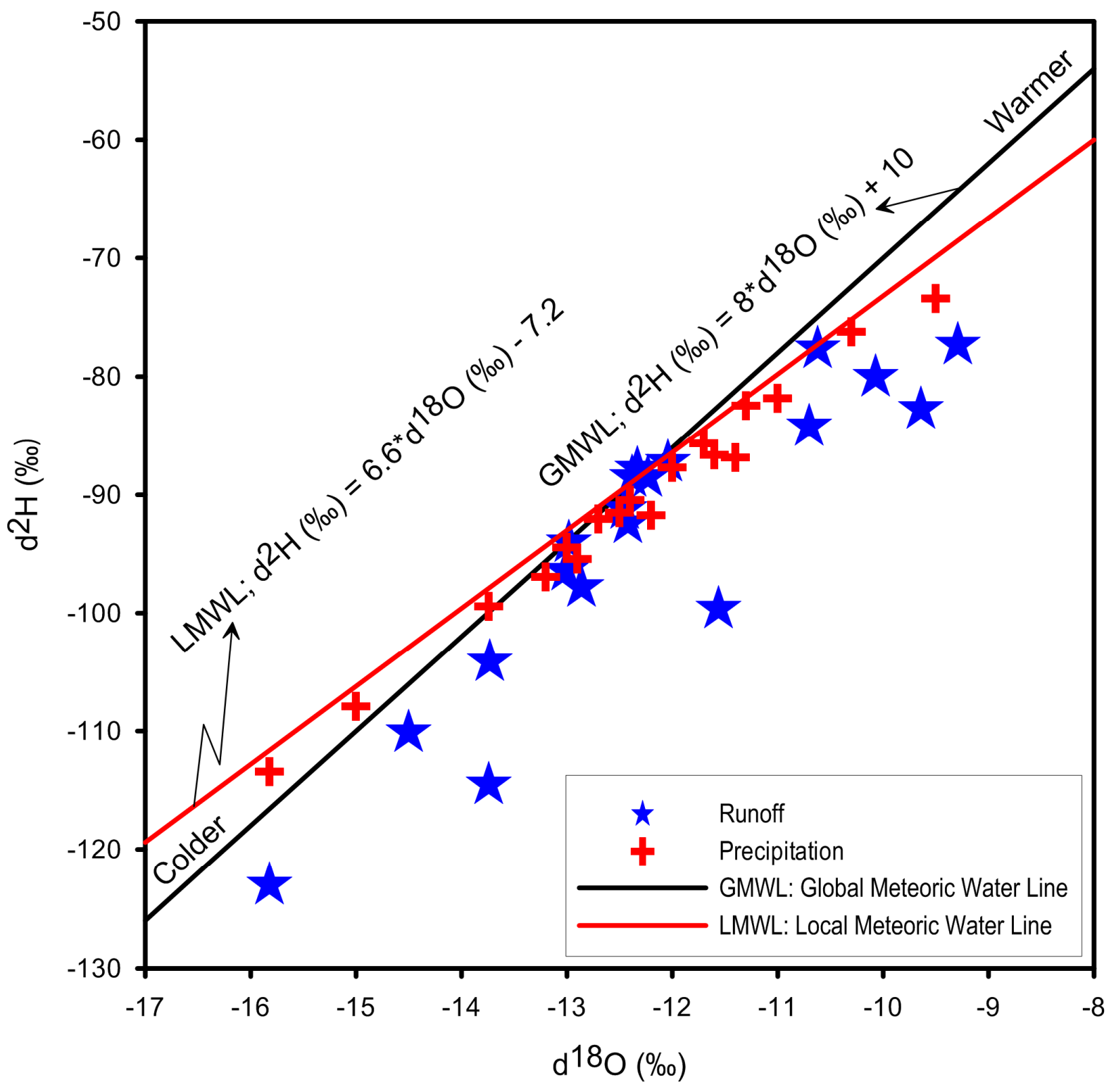

Fig 5 


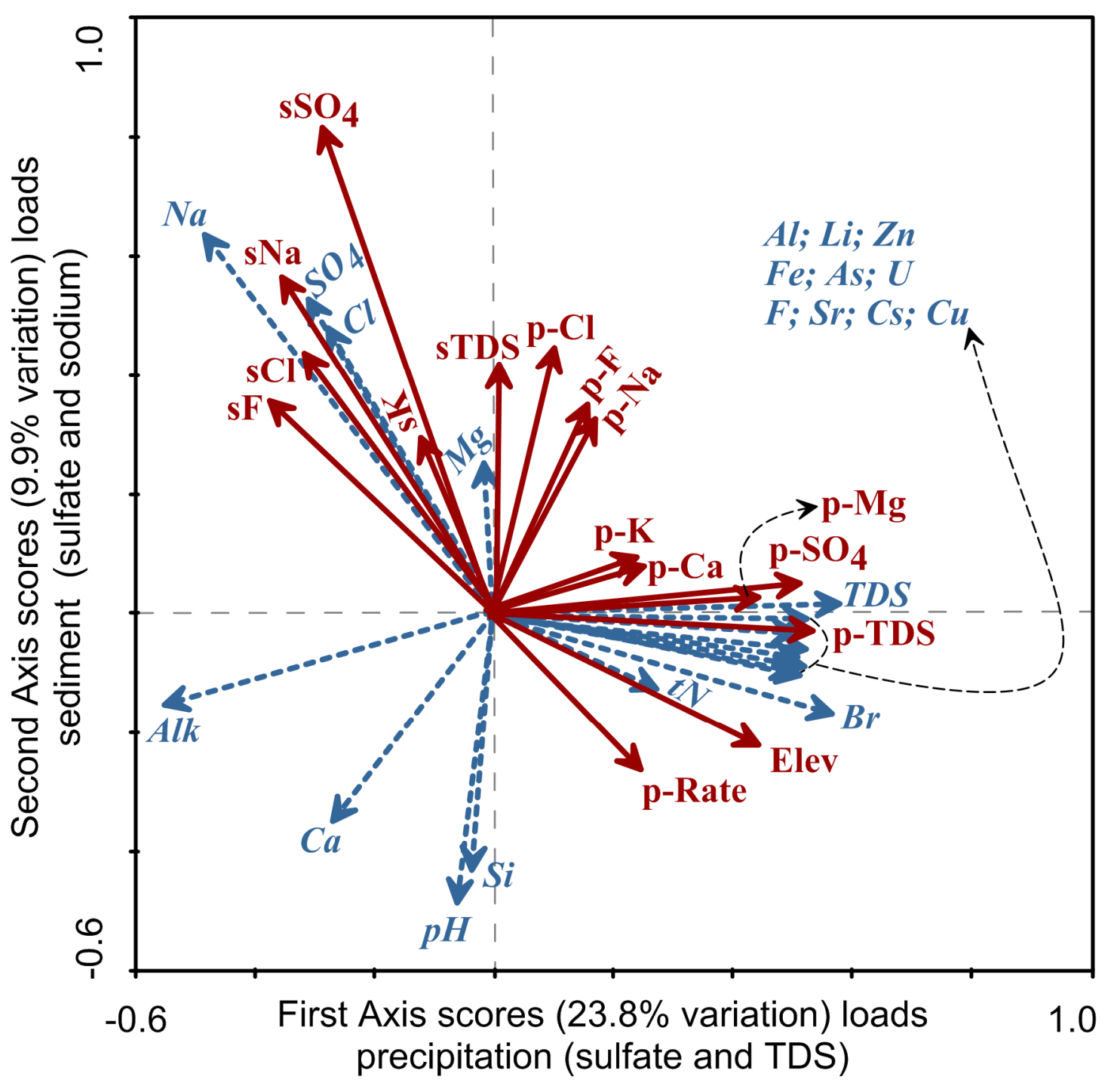

Fig 6 